\title{
Video games and scientific research
}

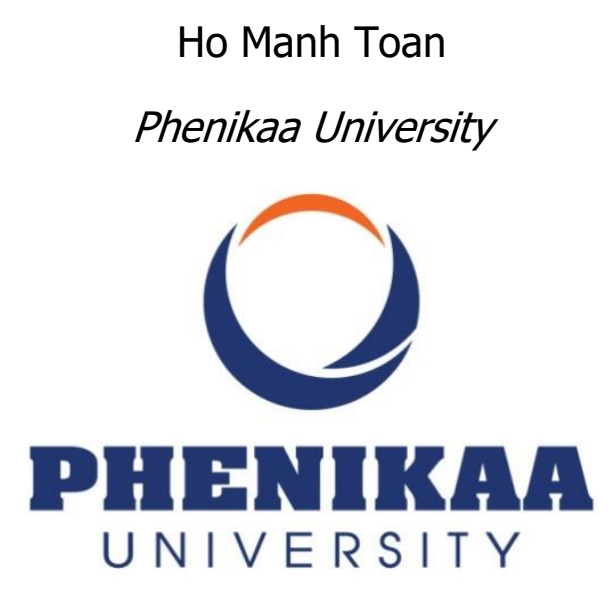

February 2, 2021

Before I became a researcher, I had already been an avid video game player. This was before video games become a mainstream obsession, when gamers can earn millions of dollars. However, video games were a luxury that I could mostly see from afar. Computers and game consoles were quite expensive back then, so the best I could do was playing whatever compatible with my old computer. Aside from that, there were some video game magazines, so at least I could read about the new and shiny piece of software.

I still carry that interest with me, especially when I earn money now. However, moving on from the pure act of playing, I see video games from a different perspective.

My media teacher at the university had done several studies on video games. He found a connection between the first-person shooter (FPS) games and modern warfare [1-3]. I was amazed when he told me that his time playing games was probably equal to his research time. My teacher argued that the FPS games provide a middle ground for the public to experience the reshaped truth of the battlefield and various aspects of war $[1,2]$. Participation in these virtual battlegrounds has created a subculture that engages its participants in arms culture and a specific political perspective [3]. Suddenly, the games that I used to play had a different connotation. Meanwhile, the term "research" was no longer just academic jargon; it was an opportunity to understand one's passion.

Thanks to technological advancement, game developers have become more ambitious with their creations. The Graphics Processing Unit (GPU), which I 
desperately wanted to own ten years ago, has provided sufficient horsepower to simulate reality. Various scientists also recognized the feature. Institute for Advanced Study's Jeffrey Fung developed a GPU-based program to simulate solar systems, stars, and planets [4]. Meanwhile, the legendary game-maker John Carmack, who ventured into virtual reality and artificial intelligence, also suggested the current gaming hardware is sufficient for AI programming $[5,6]$.

Aside from the technological perspective, the increasing immersion of video games and photorealistic graphics only suggests what my teacher hinted at in his studies: a potential for shaping reality and the public's perception. Video games have been considered a new art form, which holds up to scrutiny like films or literature $[7,8]$. In my latest study, I have tried to bridge the virtual simulation of reality in video games and the complexity of human's environmental perception [9]. Using Bayesian statistics [10], the study reported preliminary results from an investigation into the mind of Animal Crossing: New Horizons players. One of the implications indicates the game industry has yet to consider the matter of environmental conservation seriously. Even though this is from analyzing its gameplay, the findings somewhat recall news reports regarding plastic packaging problems in games $[11,12]$.

Personally, I have somewhat fulfilled my ambition: turning my passion into something meaningful. However, on a larger scale, there are many uncovered territories. There are not many efforts to connect virtual worlds with environmental perception $[13,14]$, and even less empirically. Thus, we hope to explore these topics in the future. Moreover, this is also a starting point to continue investigating the problem of business and environmental issues. Previously, we have taken a look at this matter in Vietnam [15]. It seems like a natural fit for the game industry. Many video game companies have been shifting toward a more environmental-friendly direction [12]. Indeed, they can consider the new semiconducting principle that has been proposed recently [16].

Video games have many potentials to be a powerful educational tool. Young generations like me need to understand this possibility. More than mere entertainment, or a mere money-making business, harnessing the possibilities of video games is an exciting prospect. Can we do it?

\section{References}

[1] Mantello, P. (2012). Playing discreet war in the US: Negotiating subjecthood and sovereignty through Special Forces video games. Media, War \& Conflict, 5(3), 269-283. 
[2] Mantello, P. (2013). Legitimacy and the virtual battlefield: putting the firstperson shooter on the witness stand. Australian Journal of International Affairs, 675), 638-658.

[3] Mantello, P. (2017). Military shooter video games and the ontopolitics of derivative wars and arms culture. American Journal of Economics and Sociology, 76(2), 483-521.

[4] Fung, J. (2021). Simulating Reality: Where Games and Science Meet. Institute for Advanced Study. Retrieved from https://www.ias.edu/ideas/simulating-reality-where-games-and-sciencemeet

[5] JRE Clip. (2019). Joe Asks John Carmack "How Close Are We to Artificial Intelligence?" [Video]. YouTube. Retrieved from https://www.youtube.com/watch?v=CYPQeN72LuM

[6] Coldewey, D. (2019). John Carmack steps down at Oculus to pursue AI passion project 'before I get too old'. TechCrunch. Retrieved from https://techcrunch.com/2019/11/13/john-carmack-steps-down-at-oculusto-pursue-ai-passion-project-before-i-get-too-old/

[7] Gee, J. P. (2006). Why game studies now? Video games: A new art form. Games and Culture, 1(1), 58-61.

[8] Nguyen, C. T. (2019). Games and the art of agency. Philosophical Review, 128(4), 423-462.

[9] Vuong, Q. H., et al. (2021). On the environment-destructive probabilistic trends: a perceptual and behavioral study on video game players. Technology in Society, 64, 101530.

[10] La, V. P., and Vuong, Q. H. (2019). bayesvl: Visually learning the graphical structure of Bayesian networks and performing MCMC with 'Stan'. The Comprehensive $R$ Archive Network. Available from: https://cran.rproject.org/package $=$ bayesvl.

[11] Purchese, R. (2010). How green is the games industry?. Eurogamer. Retrieved from https://www.eurogamer.net/articles/how-green-is-thegames-industry

[12] Martin, S. (2020). The inescapable impact of plastics in the video game industry. $\quad$ Eurogamer. Retrieved from https://www.eurogamer.net/articles/2020-02-16-the-inescapable-impactof-plastics-on-the-video-game-industry 
[13] Chang, A. Y. (2019). Playing nature: Ecology in video games. University of Minnesota Press.

[14] Chang, A. Y. (2011). Games as environmental texts. Qui Parle: Critical Humanities and Social Sciences, 19(2), 56-84.

[15] Vuong, Q. H., et al. (2021). Identifying the moral-practical gaps in corporate social responsibility missions of Vietnamese firms: an event-based analysis of sustainability feasibility. Corporate Social Responsibility and Environmental Management, 28(1), 30-41.

[16] Vuong, Q. H. (2021). The semiconducting principle of monetary and environmental values exchange. Economics and Business Letters, 10(3), 19. 